\title{
Analisis Sistem Program One Student One Client Pendampingan Ibu Hamil oleh Mahasiswa Keperawatan di Kota Semarang
}

\author{
Mukhamad Musta 'in ", Sri Achadi Nugraheni ${ }^{* *}$, Untung Sujianto ${ }^{* * *}$ \\ *Universitas Ngudi Waluyo, Ungaran, ** Fakultas Kesehatan Masyarakat, Universitas Diponegoro, \\ ***Prodi Ilmu Keperawatan, Fakultas Kedokteran, Universitas Diponegoro \\ E-mail: $\underline{\text { mukhamadmustain@gmail.com }}$
}

\begin{abstract}
Maternal mortality rate (MMR) and infant mortality rate (IMR) are one of the main indicators of a country's health status. MMR in Semarang was increasing since 2013 (107.95 per 100,000 live birth) become (128.05 per 100,000 live birth) in 2015. Various efforts have been made to handle the increase in maternal mortality rate in Semarang, one of them is OSOC program to accompany pregnant women. However, its implementation has not run optimally and encounters several obstacles. The purpose of the research was to analyze the input, process, and output aspects of the One Student One Client Program to accompany pregnant women by Nursing Students in Semarang.
\end{abstract}

This was qualitative research with descriptive explorative approach through indepth interview and focus of group discussion. The main informants were; Head of Health Section of Central Java Provincial Health Office and triangulation informant; 2 Heads of Public health services and 2 nurses / midwife coordinator, 2 Head of study program, 2 field supervisors, 14 nursing students and 7 pregnant women / postpartum. Data processed and analysed by content analysis method.

The result showed that the input aspect: which was human resources, had been sufficient, but insufficient in funds, infrastructure facilities only in the form of modules, the policy had not been written and there was no memorandum of understanding /
MoU between the health office and educational institutions.

Keywords: Evaluation; OSOC Program; Pregnant Woman

\section{PENDAHULUAN}

Salah satu upaya pemerintah dalam meningkatkan derajat kesehatan masyarakat adalah dengan meningkatkan pelayanan kesehatan ibu dan anak (KIA) baik dari segi jangkauan maupun mutu. Pengelolaan program KIA perlu lebih terarah agar dapat menjangkau semua ibu serta mampu menangani ibu hamil berstatus risiko tinggi. Salah satu kegiatan pokok pelayanan KIA adalah peningkatan pelayanan antenatal disemua fasilitas pelayanan kesehatan ${ }^{1}$. Sasaran program pemerintah adalah untuk mengupayakan pemeliharaan kesehatan yang mencakup $85 \%$ ibu hamil, pertolongan persalinan oleh tenaga terlatih $80 \%$ serta pemeliharaan pasca persalinan $80 \%$ bagi ibu menyusui.

Angka Kematian Ibu (AKI) di Indonesia pada tahun 2013 adalah 359/100.000 KH. AKI di Jawa Tengah mencapai 711 kasus pada tahun 2014. Angka tersebut lebih tinggi dibanding kejadian antara tahun 2010 - 2013 secara berurutan yaitu 611 (2010), 688 (2011), 675 (2012) dan $668(2013)^{2}$. AKI di Kota Semarang 
mengalami kenaikan jika dibandingkan tahun - tahun sebelumnya. Tahun 2013 yaitu 107,95 per $100.000 \mathrm{KH}$, tahun 2014 yaitu 122,25 per $100.000 \mathrm{KH}$ dan tahun 2015 yaitu 128,05 per 100.000 KH. Kematian ibu tertinggi disebabkan karena eklamsia (34\%), perdarahan (28\%), karena penyakit (26\%) dan lain - lain sebesar $12 \%$. Kematian ibu paling banyak terjadi pada masa nifas $(74,29 \%)$ sedangkan pada masa kehamilan, kematian ibu terjadi sebesar $17,14 \%$. Hal ini disertai dengan jumlah ibu hamil dan nifas risiko tinggi yang meningkat menjadi $46 \%^{3}$.

Salah satu program pemerintah yang digunakan untuk menurunkan angka kematian ibu yang dilakukan oleh pemerintah daerah yang berada di Kota Semarang yaitu program One Student One Client (OSOC). Program OSOC ini sudah mulai diterapkan sejak tahun 2015. Program OSOC merupakan kegiatan pendampingan ibu mulai dinyatakan hamil sampai masa nifas selesai, bahkan bila memungkinkan dimulai sejak persiapan calon ibu sehingga mengarah pada pendampingan kesehatan bagi keluarga. Program OSOC ini diikuti oleh mahasiswa keperawatan dan kebidanan dari berbagai institusi pendidikan yang ada di Kota Semarang ${ }^{4}$. Mahasiswa keperawatan yang terlibat dalam program OSOC adalah mahasiswa dari Program Studi S1/ Ners Keperawatan Universitas Muhammadiyah Semarang dan Program Studi S1/ Ners Keperawatan Universitas Diponegoro yang keseluruhan berjumlah 40 mahasiswa dengan dosen pembimbing 8 orang.

\section{Aplikasi dari program OSOC} pendampingan ibu hamil adalah satu mahasiswa bertanggung jawab terhadap satu ibu hamil dimana mahasiswa tersebut selalu memantau perkembangan kesehatan dari ibu hamil tersebut. Pendampingan dilakukan mulai dari pemeriksaan dengan melakukan pengkajian secara maternitas hingga melakukan pemeriksaan untuk mengetahui tanda - tanda bahaya kehamilan ataupun penyakit/infeksi yang dimiliki oleh ibu saat hamil dengan tujuan untuk mencegah komplikasi yang dapat mempengaruhi kondisi janin dalam kandungan hingga saat menghadapi masa nifas.

Keberhasilan program OSOC pendampingan ibu hamil tidak terlepas dari peran dari sistem manajemen program. Manajemen program meliputi P1 (perencanaan), P2 (penggerakan dan pelaksanaan), dan P3 (pengendalian, pengawasan dan penilaian) dalam satu kesatuan sistem yang terdiri dari input, proses, output, dan outcome. Input terdiri dari $6 \mathrm{M}$ meliputi sumber daya manusia (man), uang (money), sarana (material), metoda (method), pasar (market), serta mesin (machine $)^{5}$. Peran manajemen terletak pada proses dalam sistem. Input yang belum dikelola secara baik akan berpengaruh terhadap berjalannya sistem yang menentukan output dan outcome. Apabila tenaga dan sarana tidak sesuai dengan standar serta dana tidak tersedia sesuai dengan kebutuhan, maka sulit untuk mengharapkan output yang maksimal ${ }^{6}$. Penelitian ini bertujuan untuk menganalisis aspek input, proses, output dari program One Student One Client Pendampingan Ibu Hamil oleh Mahasiswa Keperawatan di Kota Semarang.

\section{METODE PENELITIAN}

Jenis penelitian yang digunakan adalah pendekatan kualitatif yang disajikan secara deskriptif eksploratif melalui wawancara mendalam dan focus group discussion. Subjek dalam penelitian ini ditentukan dengan metode purposive. Penentuannya didasarkan pada instansi yang melaksanakan program tersebut. Instansi yang dipilih yaitu Dinas Kesehatan Provinsi Jawa Tengah, Dinas Kesehatan Kota Semarang, Puskesmas Tlogosari Wetan dan Puskesmas Ngesrep, Program Studi S1 Keperawatan Universitas Diponegoro dan 
Program Studi S1 Keperawatan Universitas Muhamadiyah Semarang.

Informan utama yaitu Dinas

Kesehatan Provinsi Jawa Tengah (Kasie SDM Kesehatan), Dinas Kesehatan Kota Semarang (Kasie Kesehatan Ibu dan Anak), kepala puskesmas dan perawat/ bidan koordinator dari Puskesmas Ngesrep dan Tlogosari Wetan, Ketua Program Studi serta dosen pembimbing lapangan dari Universitas Muhammadiyah Semarang dan Universitas Diponegoro. Informan triangulasi dalam penelitian ini yaitu mahasiswa S1 keperawatan yang melakukan program OSOC dan ibu hamil yang mendapatkan pelayanan program.

Metode pengumpulan data dalam penelitian ini adalah data primer yang diperoleh langsung dari hasil wawancara mendalam dan focus group discussion. Data sekunder didapatkan dari hasil pencatatan dan pelaporan program OSOC. Data di analisis menggunakan metode analisis isi (content analysis) yaitu pengumpulan data, reduksi data dan kategorisasi, verifikasi kemudian disajikan dalam bentuk deskriptif.

\section{HASIL DAN PEMBAHASAN}

\section{Sumber Daya Manusia}

Ketersediaan sumber daya manusia dalam sistem kesehatan merupakan penunjang dan pendukung kesehatan yang terlibat dan bekerja serta mengabdikan dirinya seperti dalam upaya dan manajemen kesehatan, guna menjamin tercapainya derajat kesehatan masyarakat setinggi-tingginya ${ }^{7}$. Sumber daya manusia atau tenaga kesehatan merupakan sumber daya terpenting dalam menjalankan program. Karena pada dasarnya faktor manusia atau tenaga tidak hanya dilihat berdasarkan jumlah (kuantitas) semata, tetapi juga dilihat pada kemampuan dan keterampilan serta kompetensi dan kemauan untuk menjalankan tugas dengan sebaikbaiknya. Untuk meningkatkan kemampuan atau kompetensi tenaga kesehatan, banyak yang dapat dilakukan antara lain dengan pelatihan, peningkatan mutu pelayanan dan manajemen maupun dilkat-diklat lainnya. Sehingga dapat mencapai kemampuan secara efektif dan efisien.

Berdasarkan wawancara mendalam dengan informan utama, menyatakan bahwa sumber daya manusia yang terlibat dalam program OSOC sudah mencukupi, sebagaimana pendapat informan utama sebagai berikut:

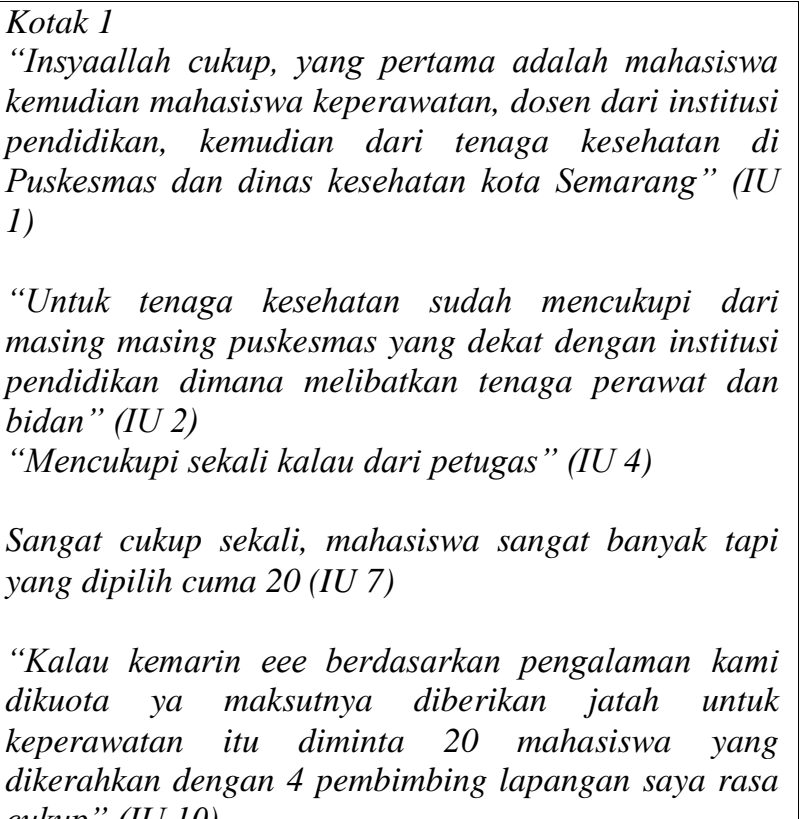
cukup" (IU 10)

Pernyataan di atas juga diperkuat oleh pernyataan yang diungkapkan oleh beberapa informan triangulasi mahasiswa tentang ketersediaan tenaga petugas kesehatan, bahwa untuk sumber daya manusia kesehatan yang terlibat selama ini secara kuantitas sudah cukup, hal tersebut diungkapkan dalam kotak 2 dibawah ini.

\footnotetext{
Kotak 2

“ Mencukupi mahasiswanya 20 dibagi menjadi 5 kelompok tiap kelompok mendapat 1 pembimbing dari akademik dan puskesmas" (IT 11)

“Cukup” (IT 12)

“Cukup” (IT 13)
} 
Berdasarkan hasil penelitian, diperoleh bahwa pada sumber daya manusia kesehatan yang terlibat dalam program OSOC sudah mencukupi untuk pelaksanaan program. Selain itu tenaga kesehatan yang terlibat sudah mendapatkan pelatihan tentang progam OSOC dan mendapatkan sosialisasi sebelum program dilaksanakan. Pelatihan berperan dalam meningkatkan kemampuan dan keterampilan para petugas kesehatan ${ }^{8}$. Hal senada juga diungkapkan penelitian sebelumnya yang menyatakan bahwa pelatihan juga mempengaruhi terhadap peningkatan kerja seseorang ${ }^{9}$.

\section{Pendanaan}

Hasil wawancara mendalam pada aspek pendanaan bahwa dalam program OSOC sudah terdapat alokasi dana untuk pelaksanaan program, tetapi jumlahnya terbatas dan kurang mencukupi. Hal tersebut tertuang dalam kotak berikut.

\section{Kotak 3}

“Kurang .... Karena dari DKK sebagai yang punya wilayah kan juga perlu mengadakan evaluasi walaupun kita hanya sebagai fasilitator kegiatan propinsi ke masyarakat. Karena kita pernah melakukan evaluasi kegiatan osoc memakai biaya sendiri” (IU 2)

“Kurang cukup" (IU 7)

"Kalau kami DPL tiap bulan dapat Rp25.000, mahasiswa dapat Rp 10.000 perbulan kalau untuk BBM dan biaya komunikasi dari sendiri jadi Dak cukup mas" (IU 9)

Pernyataan di atas juga diperkuat oleh pernyataan yang diungkapkan oleh beberapa informan triangulasi mahasiswa tentang dana kegiatan program, bahwa untuk dana yang digunanakan untuk pelaksanaan program masih kurang, hal tersebut diungkapkan dalam kotak dibawah ini.

Kotak 4

“Nggak cukup” (IT 11)
"Saya pribadi Nggak cukup sih kalau segitu selain bolak balik setiap bulan kesana" (IT 12)

“Tidak cukup” (IT 13)

“Tidak cukup” (IT 14)

Tercapainya target kesehatan harus didukung oleh ketersediaan dana yang mencukupi. ${ }^{8}$ Ketersediaan dana merupakan unsur terpenting berjalannya suatu program sehingga semua kegiatan harus dialokasikan dana yang cukup dan tepat sasaran. Tidak tersedianya dana dapat menyebabkan kesulitan dalam pelaksanaan program dan menghasilkan hasil yang tidak maksimal. Berdasarkan hasil penelitian diperoleh bahwa pelaksanaan program OSOC didanai oleh Dinas Kesehatan Provinsi Jawa Tengah yang dianggarkan melalui dana APBD 1, tetapi jumlahnya sangat terbatas.

\section{Sarana Prasarana}

Hasil wawancara pada aspek sarana dan prasarana dengan informan utama menjelaskan bahwa sarana dan prasarana yang disediakan hanya berupa modul dengan jumlah terbatas dan belum mencukupi. Hal tersebut tertuang dalam kotak berikut.

Kotak 5

"Hanya menyediakan modul. Untuk sarana prasasara, yang lain kita nggak menyediakan, mahasiswa bawa sendiri dia bawa tensi ya bawa sendiri “ (IU 1)

“Kuesioner saja, buku KIA, buku pedoman juknis" (IU 2)

"Kalau dari pendokumentasian sudah disiapkan dari dinas, terkait transport gak ada, leaflet kurang tahu" (IU 7)

Pernyataan di atas senada dengan pernyataan yang diungkapkan oleh beberapa informan triangulasi mahasiswa tentang sarana dan prasarana kegiatan program, bahwa untuk sarana dan prasarana dalam pelaksanaan program masih terbatas dan 
belum mencukupi, hal tersebut diungkapkan dalam kotak dibawah ini.

\section{Kotak 6}

"Nggak ada hanya buku panduan dan masih baru" (IT 11)

"Nggak ada dikasih buku form penilaian aja" (IT 12)

"Leaflet, tensi ada dari puskesmas tapi kan terbatas dan lainnya mandiri dari mahasiswa sendiri seperti nursing kit" (IT 1)

"Nggak ada leaflet buat sendiri, tensi bawa sendiri" (IT 10)

“Bawa sendiri”( IT 7)

Berdasarkan hasil penelitian diperoleh bahwa dari sarana dan prasarana program OSOC belum menunjang dan belum memadai secara baik dan lengkap untuk keberlangsungan program. Hal ini tentunya akan menghambat program. Tanpa peralatan yang memadai maka program OSOC tidak akan berhasil dengan baik dan terkesan pemberian pelayanan kepada ibu hamil dilakukan seadanya. Hal tersebut sesuai dengan pernyataan oleh Haryani yang menerangkan bahwa sarana dan prasarana merupakan factor yang paling berpengaruh dalam kinerja perawat dalam pemberian suatu pelayanan $^{10}$.

\section{Metode Pendampingan}

Hasil wawancara pada aspek metode dengan informan utama bahwa metode yang digunakan dalam pelayanan terhadap ibu hamil adalah pendampingan ibu hamil/ nifas, anamnesa, pemeriksaan, serta penyuluhan yang didokumentasikan berupa asuhan keperawatan. Hal tersebut tertuang dalam kotak berikut.

\section{Kotak 7}

"Kegiatan dilapangan mendampingi ibu hamil dari ibu hamil, ibu bersalin dan ibu nifas, jadi upaya pendampingan disini adalah untuk meningkatkan upaya promotif dan preventif untuk meningkatkan kesehatan ibu dan anak dan memastikan ibu bersalin di fasilitas kesehatan" (IU 1)

"Mahasiswa mendampingi ibu hamil mereka melihat dari buku KIA kalau ada masalah mereka memberikan penyuluhan atau KIE kepada ibu hamil dan evaluasi, dokumentasinya berupa asuhan keperawatan. Nanti dilaporkan ke perawat puskesmas di puskesmas masing masing” (IU 2)

"Pendampingan ibu hamil resti jadi yaa mulai dari anamnesa sampai evaluasi "(IU5)

"Kunjungan dan Pendampingan aja ke ibu hamil" ( IU 6)

Pernyataan di atas senada dengan pernyataan yang diungkapkan oleh beberapa informan triangulasi mahasiswa dan ibu hamil tentang metode pelayanan, bahwa metode pelayanan berupa pendampingan ibu hamil yang didokumentasikan berupa asuhan keperawatan yang diungkapkan dalam kotak dibawah ini

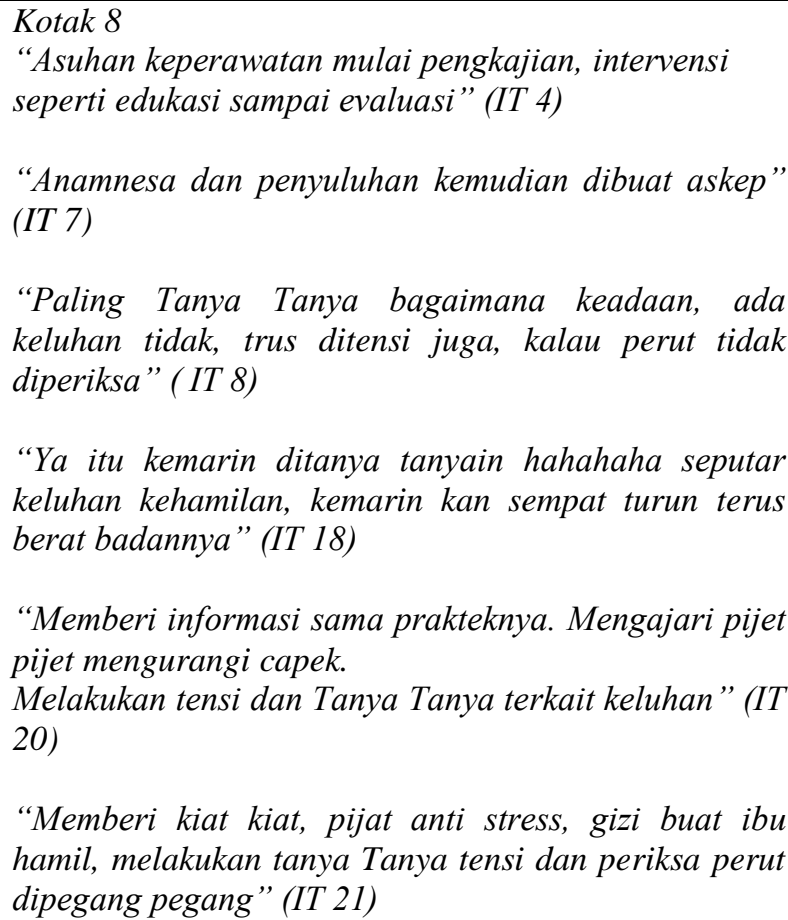

"Paling Tanya Tanya bagaimana keadaan, ada keluhan tidak, trus ditensi juga, kalau perut tidak diperiksa” ( IT 8)

"Ya itu kemarin ditanya tanyain hahahaha seputar keluhan kehamilan, kemarin kan sempat turun terus berat badannya" (IT 18)

"Memberi informasi sama prakteknya. Mengajari pijet pijet mengurangi capek.

Melakukan tensi dan Tanya Tanya terkait keluhan" (IT 20)

"Memberi kiat kiat, pijat anti stress, gizi buat ibu hamil, melakukan tanya Tanya tensi dan periksa perut dipegang pegang” (IT 21)

Hasil wawancara pada aspek metode dengan informan utama dan informan triangulasi bahwa kebijakan program OSOC belum bersifat tertulis, belum tersosialisasikan dengan baik dan belum ada 
MoU antara dinas kesehatan dengan institusi pendidikan. Hal tersebut tertuang dalam kotak berikut.

\section{Kotak 9}

“Ada berupa himbauan saja " (IU 2)

"Jelas arahnya kesana..harapan kita bisa jalan...SK dari dinas saya belum lihat langsung....belum ada” (IU 3)

"Kita tidak tahu hanya himbauan dari dinas" (IU 4)

"MoU dengan dinas kesehatan mboten wonten". (IU 1)

"Mestinya ada tapi saya belum lihat". (IU 2)

Saya kurang tahu tentang MOU, dinas hanya sosialisasi dan mengundang. Sepertinya kalau MOU kok tidak ada, kemarin juga jadi masalah kita minta sertifikat sebagai bukti mahasiswa kami besuk kalau lulus kuliah kan ada surat keterangan pendamping ijasah (IU 10).

Kurang tahu (IT 1)

Dari hasil penelitian didapatkan bahwa pelayanan yang diberikan berupa pendampingan ibu hamil melalui upaya preventif, promotif dan motivasi kepada ibu hamil untuk memeriksakan kehamilannya. Dalam pemberian pelayanan oleh mahasiswa kepada ibu hamil bahwa sudah sesuai dengan petunjuk pelaksanaan dan petunjuk teknis serta sesuai kebutuhan ibu hamil dilapangan.

Kebijakan tentang program OSOC sepenuhnya belum diketahui oleh para pelaksana program dan belum tersosialisasi dengan baik. Disamping itu kebijakan belum bersifat tertulis dan masih berupa himbauan dari dinas. Kerjasama berupa MoU antara pembuat program dan pelaksana lapangan belum tersedia sehingga batasan hak dan kewajiban belum jelas dan juga akan berimbas terhadap pelayanan di masyarakat.

\section{KESIMPULAN}

Pada aspek input dari program OSOC pendampingan ibu hamil dapat disimpulkan yaitu sumber daya manusia yang terlibat telah cukup dan telah mengikuti pelatihan dan sosialisasi program. Terdapat dana untuk pelaksanaan program yang berasal dari APBD 1, tetapi dana belum mencukupi untuk pelaksanaan program secara maksimal. Sarana dan prasarana untuk program OSOC hanya berupa modul/ buku petunjuk teknis dan pelaksanaan dengan kondisi baik, tetapi jumlah terbatas dan belum menunjang secara baik dan lengkap. Metode pelayanan berupa pendampingan ibu hamil melalui upaya promotif dan preventif yang didokumentasikan dalam bentuk asuhan keperawatan yang diberikan sesuai kebutuhan ibu hamil. Kebijakan program OSOC sudah ada tetapi belum bersifat tertulis, selain itu kebijakan belum tersosialisasikan dengan baik, dan belum adanya bukti kerjasama/ MoU antara pemilik program dengan institusi pendidikan sebagai pelaksana dilapangan.

Dinas Kesehatan diharapkan menyusun kebijakan secara tertulis, membuat MoU dengan institusi pendidikan, meningkatkan koordinasi antar sektor dan menganjurkan kepada institusi pendidikan untuk ikut serta mengeluarkan dana untuk keberlanjutan program OSOC.

\section{UCAPAN TERIMA KASIH}

Penulis mengucapkan terima kasih kepada Dinas Kesehatan Provinsi Jawa Tengah, Dinas Kesehatan Kota Semarang, Puskesmas Ngesrep dan Tlogosari Wetan, serta Universitas Muhammadiyah Semarang dan Universitas Diponegoro atas dukungannya sebagai responden penelitian.

\section{DAFTAR PUSTAKA}

1. Departemen Kesehatan Republik Indonesia. Nifas dan Perawatannya. Jakarta: Departemen Kesehatan Republik Indonesia, 1997.

2. Dinas Kesehatan Provinsi Jawa Tengah. Profil Dinas Kesehatan Provinsi Jawa 
Tengah. Semarang: Dinas Kesehatan Provinsi Jawa Tengah, 2015.

3. Dinas Kesehatan Kota Semarang. Profil Dinas Kesehatan Kota Semarang. Semarang: Dinas Kesehatan Kota Semarang, 2015.

4. Dinas Kesehatan Provinsi Jawa Tengah. Buku Pedoman Pelaksanaan Pendampingan Ibu Hamil Bagi Mahasiswa. Semarang: Dinas Kesehatan Provinsi Jawa Tengah, 2015.

5. Muninjaya AAG. Manajemen Kesehatan. Jakarta: EGC Kedokteran, 2004.

6. Azwar A. Pengantar Administrasi Kesehatan. Jakarta Bin Aksara 1996; 123-142.

7. Hersey P, Blancard KH. Manajemen Perilaku Organisasi: Pendayagunaan Sumber Daya Manusia. 4th ed. Jakarta: Erlangga, 1995.

8. Wiku A. Sistem Kesehatan. Jakarta: Rajawali Press, 2014.

9. Yudaningsih Y, Kana NL, Sujianto U. Pengaruh Pelatihan kepemimpinan spiritual terhadap kinerja ketua tim keperawatan rumah sakit daerah kota Semarang. J Manaj Kesehat Indones 2016; 4: 242-249.

10. Haryani S. Faktor-Faktor yang Mempengaruhi Kinerja Perawat dalam Pelaksanaan Terapi Bermain pada Anak Usia Pra Sekolah di Ruang Rawat Inap Anak RSUP Dr Kariadi Semarang. Universitas Diponegoro, http://eprints.undip.ac.id/39772/ (2012). 